\title{
Dopuszczalność prowadzenia mediacji w postępowaniu w sprawach z zakresu ubezpieczeń społecznych (w postępowaniu przed organem rentowym)
}

\section{Wprowadzenie}

Postępowanie w sprawach z zakresu ubezpieczeń społecznych stanowi zbiorczą kategorię obejmującą różne postępowania regulowane prawem, które dotyczą sfery zabezpieczenia społecznego. Mają one charakter administracyjnych postępowań szczególnych, do których w różnym zakresie stosuje się Kodeks postępowania administracyjnego ${ }^{1}$. Nowelizacja k.p.a. z dnia 7 kwietnia 2017 r. $^{2}$ wprowadziła wiele nowych instytucji, nieznanych do tej pory ogólnemu postępowaniu administracyjnemu. Należy do nich m.in. mediacja. Uzasadnia to dokonanie oceny, czy dotyczące jej przepisy znajdą zastosowanie w postępowaniu w sprawach z zakresu ubezpieczeń społecznych, a jeśli tak, to w jakim stopniu.

\section{Stosowanie k.p.a. do postępowania w sprawach z zakresu ubezpieczeń społecznych}

Zgodnie z art. 180 § 1 k.p.a. w sprawach z zakresu ubezpieczeń społecznych stosuje się przepisy k.p.a., chyba że przepisy dotyczące

${ }^{1}$ Ustawa z dnia 14 VI 1960 r. - Kodeks postępowania administracyjnego (tekst jedn. Dz.U. 2017, poz. 1257), dalej „k.p.a.”.

${ }^{2}$ Ustawa z dnia 7 IV 2017 r. o zmianie ustawy - Kodeks postępowania administracyjnego i niektórych innych ustaw (Dz.U. poz. 935). 
ubezpieczeń ustalają odmienne zasady postępowania w tych sprawach. Stosownie zaś do art. 123 ustawy o systemie ubezpieczeń społecznych ${ }^{3}$ w sprawach uregulowanych ustawą stosuje się przepisy k.p.a., chyba że ustawa stanowi inaczej. Natomiast art. 124 ustawy o emeryturach i rentach z Funduszu Ubezpieczeń Społecznych ${ }^{4}$ wskazuje, że w postępowaniu o świadczenia określone w tej ustawie stosuje się przepisy k.p.a., chyba że stanowi ona inaczej. Podobna regulacja obecna jest $\mathrm{w}$ przepisach dotyczących zaopatrzenia emerytalnego funkcjonariuszy służb mundurowych ${ }^{5}$ (art. 11 u.z.e.f.) oraz zaopatrzenia emerytalnego żołnierzy zawodowych i ich rodzin ${ }^{6}$ (art. 11 u.z.z.r.). Można ją również zrekonstruować na gruncie przepisów o ubezpieczeniu społecznym rolników ${ }^{7}$ (art. 123 w zw. z art. 52 ust. 1 u.s.r.).

W literaturze przedmiotu podkreśla się, że przytoczone przepisy są ze sobą wzajemnie powiązane i w istocie wyrażają jedną normę prawną ${ }^{8}$. Zakłada ona, że w postępowaniu w sprawach z zakresu ubezpieczeń społecznych znajdują zastosowanie wszystkie przepisy k.p.a., które nie pozostają w oczywistej sprzeczności z przepisami procesowymi zawartymi w przepisach szczególnych dotyczących tych spraw, a jednocześnie nie jest możliwe zbudowanie wykładni zapewniającej ich współstosowanie ${ }^{9}$. Wskazać przy tym należy, że w praktyce - mimo braku sprzeczności między regulacją k.p.a. a szczególnymi przepisami

${ }^{3}$ Ustawa z dnia 13 X 1998 r. o systemie ubezpieczeń społecznych (tekst jedn. Dz.U. 2017, poz. 1778), dalej „ustawa systemowa”.

${ }^{4}$ Ustawa z dnia 17 XII 1998 r. o emeryturach i rentach z Funduszu Ubezpieczeń Społecznych (tekst jedn. Dz.U. 2017, poz. 1383), dalej „ustawa emerytalna”.

${ }^{5}$ Ustawa z dnia 18 II 1994 r. o zaopatrzeniu emerytalnym funkcjonariuszy Policji, Agencji Bezpieczeństwa Wewnętrznego, Agencji Wywiadu, Służby Kontrwywiadu Wojskowego, Służby Wywiadu Wojskowego, Centralnego Biura Antykorupcyjnego, Straży Granicznej, Straży Marszałkowskiej, Służby Ochrony Państwa, Państwowej Straży Pożarnej, Służby Celno-Skarbowej i Służby Więziennej oraz ich rodzin (tekst jedn. Dz.U. 2018, poz. 132 ze zm.), dalej „u.z.e.f.".

${ }^{6}$ Ustawa z dnia 10 XII 1993 r. o zaopatrzeniu emerytalnym żołnierzy zawodowych i ich rodzin (tekst jedn. Dz.U. 2017, poz. 2225 ze zm.), dalej „u.z.z.r.”.

${ }^{7}$ Ustawa z dnia 20 XII 1990 r. o ubezpieczeniu społecznym rolników (tekst jedn. Dz.U. 2017, poz. 2336 ze zm.), dalej „u.s.r.”.

${ }^{8}$ Por. S. Gajewski, Stosowanie Kodeksu postepowania administracyjnego do postęowania o świadczenia emerytalno-rentowe. Konstrukcja i wybrane zagadnienia szczegółowe, „Z Zagadnień Zabezpieczenia Społecznego" 2018, nr 7, s. 24; M. Gajda-Durlik, Regulacja prawna postępowania w sprawach emerytalno-rentowych - uwagi na tle ujęcia legislacyjnego po nowelizacji w 2011 r., "Administracja. Teoria. Dydaktyka. Praktyka” 2011, nr 3, s. 49.

${ }_{9}^{9}$ Zob. S. Gajewski, Stosowanie Kodeksu...; A. Wróbel, Stosowanie zasad ogólnych postępowania administracyjnego w postępowaniach w sprawach z zakresu ubezpieczeń społecznych, 
procesowymi z zakresu ubezpieczeń społecznych - niektóre rozwiązania przewidziane w k.p.a. nie znajdą zastosowania do postępowania w tych sprawach. Nie zawsze bowiem przepisy prawa materialnego w tej dziedzinie umożliwią wykorzystanie unormowań procesowych zawartych w k.p.a. ${ }^{10}$

\section{Wprowadzenie mediacji do postępowania administracyjnego}

Wspomniana nowelizacja k.p.a. wprowadziła możliwość prowadzenia mediacji w toku ogólnego postępowania administracyjnego (art. 96a-n k.p.a.). Stanowi to realizację postulatów wielokrotnie zgłaszanych $\mathrm{w}$ doktrynie ${ }^{11}$. W literaturze przedmiotu zauważa się, że takie rozwiązanie stanowi przejaw dążenia do zmiany przyjętego wiele lat temu modelu rozstrzygania spraw administracyjnych, otwierając go na potrzebę uwzględniania zróżnicowanych poglądów, pogodzenia pozostających w konflikcie interesów, a przede wszystkim - włączenia stron do kręgu podmiotów odpowiedzialnych za wynik postępowania ${ }^{12}$. Nie bez znaczenia jest także zmiana podejścia organów administracji publicznej do stron postępowania i prowadzonych spraw. Mowa tu o złagodzeniu nierównorzędności stosunku administracyjnoprawnego, która wynika z jego władczego i jednostronnego charakteru ${ }^{13}$.

W punkcie wyjścia można przyjąć, że tak ogólnie ujęte cele mediacji w postępowaniu administracyjnym mogłyby być również realizowane

w: Procedury w ubezpieczeniach emerytalnym i rentowych, pod red. B. Wagner, M. Nowak, Gniezno 2008, s. 42.

${ }^{10}$ Por. K. Antonów, Wybrane zagadnienia stosowania przepisów k.p.a. w postępowaniu w sprawach z zakresu ubezpieczeń społecznych, "Praca i Zabezpieczenie Społeczne" 2007, nr 10, s. 29; S. Gajewski, Stosowanie Kodeksu..., s. 27.

${ }^{11}$ Zob. W. Federczyk, Mediacja w postępowaniu administracyjnym i sądowoadministracyjnym, Warszawa 2013, s. 231-234; Z. Kmieciak, Mediacja i koncyliacja w prawie administracyjnym, Kraków 2004, s. 173-183; M. Tabernacka, Opinia dotyczaca propozycji w przedmiocie mediacji przedstawionych w toku prac Zespołu do spraw reformy postępowania administracyjnego, http:www.nsa.gov.pl (dostęp: 7 VI 2018); J. Wegner-Kowalska, Koncepcja właczenia instytucji mediacji do Kodeksu postępowania administracyjnego, „Przegląd Prawa Publicznego" 2016, nr 11, s. 56, 67.

${ }^{12}$ Zob. J. Wegner-Kowalska, Mediacja w sprawach administracyjnych - pytania i watpliwości, "Zeszyty Naukowe Sądownictwa Administracyjnego" 2017, nr 6, s. 40.

${ }^{13}$ Por. uzasadnienie projektu ustawy o zmianie ustawy - Kodeks postępowania administracyjnego oraz niektórych innych ustaw (druk sejmowy nr 1183/VIII kadencja, s. 36-37). 
w postępowaniach w sprawach z zakresu ubezpieczeń społecznych. Konstatacja ta ma znaczenie o tyle, że na gruncie obowiązujących przepisów szczególnych dotyczących wspomnianych spraw nie można wskazać regulacji wprost wyłączających zastosowanie art. 96a-n k.p.a., jak również unormowań pozostających z nimi w sprzeczności. Oznacza to w szczególności, że ocena dopuszczalności prowadzenia mediacji $\mathrm{w}$ toku postępowania $\mathrm{w}$ sprawach z zakresu ubezpieczeń społecznych musi odwoływać się z jednej strony do ogólnych warunków przewidzianych przez k.p.a., z drugiej zaś - do właściwości prawa ubezpieczeń społecznych jako prawa materialnego.

\section{Istota mediacji w postępowaniu administracyjnym}

Mediacja jest formą postępowania wyjaśniającego w postępowaniu administracyjnym. Służy bowiem realizacji celów tej fazy postępowania, czyli wyjaśnieniu okoliczności faktycznych i prawnych sprawy ${ }^{14}$. W postępowaniu mediacyjnym można wyróżnić trzy etapy: (1) wszczęcie postępowania, (2) postępowanie właściwe oraz (3) zakończenie postępowania. Pierwszy etap sprowadza się do ustalenia po stronie ewentualnych uczestników mediacji woli wzięcia w niej udziału. Mediacja ma bowiem w każdym przypadku charakter dobrowolny (art. 96a § 2 k.p.a.). W tym etapie organ administracji publicznej kieruje do stron z urzędu lub na wniosek jednej z nich zawiadomienie o możliwości przeprowadzenia mediacji (art. 96b $\S 1$ k.p.a.), a w razie gdy wszyscy jej uczestnicy wyrażą zgodę na udział w niej - wydaje postanowienie o skierowaniu sprawy do mediacji (art. $96 \mathrm{~d} \S 1$ k.p.a.). Odracza on przy tym termin załatwienia sprawy nie dłużej niż o dwa miesiące (art. 96e $\S 1$ k.p.a.). W drugim etapie postępowania mediacyjnego wyznaczony w postanowieniu o skierowaniu sprawy do mediacji mediator prowadzi, z zachowaniem zasad bezstronności, niejawności i dobrowolności, czynności zmierzające do ustalenia przy udziale uczestników mediacji stanu faktycznego i prawnego sprawy oraz sposobu jej załatwienia. Trzeci etap mediacji rozpoczyna się z chwilą upływu czasu wyznaczonego przez organ na mediację, rezygnacji z dalszego udziału w niej przez jednego z uczestników lub poczynienia przez nich zgodnych ustaleń co do sposobu załatwienia sprawy. $W$ tej fazie mediator sporządza

\footnotetext{
${ }^{14}$ Zob. S. Gajewski, Kodeks postępowania administracyjnego. Nowe instytucje, Warszawa 2017, s. 11.
} 
protokół z przebiegu mediacji (art. 96m § 1 k.p.a.), odzwierciedlając w nim w szczególności dokonane ustalenia co do sposobu załatwienia sprawy (art. $96 \mathrm{~m} \S 2$ pkt 4 k.p.a.) i przekazuje go organowi prowadzącemu postępowanie (art. $96 \mathrm{~m} \S 3$ k.p.a.). W przypadku gdy w wyniku mediacji poczynione zostały $w$ granicach obowiązującego prawa ustalenia dotyczące sposobu załatwienia sprawy, organ administracji publicznej załatwia sprawę zgodnie z tymi ustaleniami (art. 96n § 1 k.p.a.).

\section{Dopuszczalność mediacji w postępowaniu administracyjnym}

W literaturze przedmiotu podkreśla się, że mediacja w ogólnym postępowaniu administracyjnym nie jest konstrukcja prawnie nieograniczoną. Ustawodawca wprowadził bowiem katalog przesłanek, od których spełnienia uzależniona jest możliwość jej zastosowania w konkretnej sprawie $^{15}$. Zagadnienie dopuszczalności mediacji zostało unormowane w art. 96a § 1 i 3 k.p.a. Przewidują one, że w toku postępowania może być przeprowadzona mediacja, jeżeli pozwala na to charakter sprawy (art. 96a § 1 k.p.a.), a celem mediacji jest wyjaśnienie i rozważenie okoliczności faktycznych i prawnych sprawy oraz dokonanie ustaleń dotyczących jej załatwienia w granicach obowiązującego prawa, w tym przez wydanie decyzji lub zawarcie ugody (art. 96a § 3 k.p.a.). Przyjmuje się przy tym, że z przywołanych przepisów wynika, iż dopuszczalność mediacji uzależniona jest od spełnienia dwóch przesłanek: zawisłości sprawy oraz charakteru sprawy. Pierwsza zakłada, że jest to możliwe jedynie wówczas, gdy postępowanie w sprawie zostało wszczęte i się toczy ${ }^{16}$. Druga z kolei odnosi się do przedmiotowych i podmiotowych cech sprawy administracyjnej rozstrzyganej w danym postępowaniu. Szczegółowe znaczenie tej przesłanki jest szeroko charakteryzowane w literaturze przedmiotu. W literaturze przedmiotu podkreśla się przy tym, że sposób sformułowania tej przesłanki jest nadmiernie ogólny i nieprecyzyjny ${ }^{17}$.

${ }^{15}$ Zob. A. Kocot-Łaszczyca, G. Łaszczyca, Mediacja w ogólnym postępowaniu administracyjnym, Warszawa 2018, s. 63.

${ }_{16}$ Zob. B. Adamiak, Art. 96a, w: B. Adamiak, J. Borkowski, Kodeks postępowania administracyjnego. Komentarz, Warszawa 2017, s. 496; S. Gajewski, Kodeks postepowania..., s. 6; P. Przybysz, Kodeks postępowania administracyjnego. Komentarz, Warszawa 2017, s. 341; R. Kędziora, Kodeks postępowania administracyjnego. Komentarz, Warszawa 2017, s. 553.

17 Zob. A. Kocot-Łaszczyca, G. Łaszczyca, op. cit., s. 64. 
B. Adamiak wskazuje, że przesłankę tę należy wiązać z regulacją norm prawa materialnego, która budzi wątpliwości interpretacyjne, zawiera upoważnienie do uznania administracyjnego lub pojęcia niedookreślone. W jej ocenie rozważenie zasadności przeprowadzenia mediacji uzasadnione jest więc jedynie wówczas, gdy zachodzi konieczność ustalenia treści normy prawnej w wyniku złożonego procesu wykładni, norma prawna nie nakazuje wyprowadzenia konsekwencji prawnych lub uzależnia ich wyprowadzenie od spełnienia wartości mieszczących się $\mathrm{w}$ pojęciu nieostrym ${ }^{18}$.

Z kolei R. Kędziora ${ }^{19}$ podnosi za M. Sieniućc ${ }^{20}$, że w sprawie administracyjnej, ze względu na jej charakter, można przeprowadzić mediację w każdym przypadku, gdy przepisy prawa materialnego wprowadzają po stronie organu kompetencję do posłużenia się uznaniem administracyjnym. W ocenie tych autorów związany charakter decyzji kończącej postępowanie i załatwiającej sprawę nie wyłącza jednak w każdym przypadku możliwości przeprowadzenia w niej mediacji. Może ona bowiem dotyczyć pewnych pobocznych kwestii, np. terminu wykonania przez stronę nakładanego na nią w drodze decyzji obowiązku.

W ocenie P. Przybysza mediacja dopuszczalna jest we wszystkich sprawach, w których możliwe jest zawarcie ugody administracyjnej, a zatem wówczas, gdy w postępowaniu występują co najmniej dwie strony o spornych interesach. Zdaniem tego autora przypadki te nie wyczerpują jednak wszystkich sytuacji, w których charakter sprawy pozwala na przeprowadzenie mediacji. Podkreśla on bowiem, że również i w innych przypadkach możliwe jest zastosowanie tej formy postępowania wyjaśniającego ${ }^{21}$.

Natomiast A. Jakubowski podnosi, że w postępowaniu może być przeprowadzona mediacja, jeśli uwidacznia się w nim konflikt między określonymi wartościami lub interesami różnych podmiotów albo podstawą prawną dla rozstrzyganej w nim sprawy są przepisy pozwalające na różne rozstrzygnięcia. W tym ujęciu mediacja może być przeprowadzona w postępowaniach wielostronnych lub takich, w których prowadzący je organ administracji publicznej działa w warunkach

${ }^{18}$ Zob. B. Adamiak, op. cit., s. 496-497.

${ }^{19}$ Zob. R. Kędziora, op. cit., s. 553.

${ }^{20}$ Zob. M. Sieniuć, Mediacja w postępowaniu administracyjnym, w: Prawo procesowe administracyjne, seria System prawa administracyjnego, pod red. R. Hausera, Z. Niewiadomskiego, A. Wróbla, t. 9, Warszawa 2017, s. 249.

${ }^{21}$ Zob. P. Przybysz, op. cit., s. 342-343. 
dyskrecjonalności: korzysta z uznania administracyjnego lub stosuje pojęcia niedookreślone ${ }^{22}$.

Zdaniem S. Gajewskiego mediacja może być prowadzona tylko $\mathrm{w}$ tych postępowaniach, w których po stronie organu istnieje luz dowodowy oraz luz interpretacyjny lub uznanie administracyjne. Mowa tu więc o przypadkach, w których regulacja postępowania dowodowego została oparta na swobodnej ocenie dowodów, a stosowane w sprawie przepisy prawa posługują się pojęciami niedookreślonymi lub przewidują po stronie organu administracji publicznej upoważnienie do posłużenia się uznaniem administracyjnym. W innych sytuacjach organ administracji publicznej nie może bowiem czynić jakichkolwiek ustaleń w uzgodnieniu ze stroną (stronami), ponieważ są one w pełni i wprost determinowane przez przepisy prawa ${ }^{23}$.

W ocenie A. Kocot-Łaszczycy i G. Łaszczycy mediacja dopuszczalna jest w sprawach, w których rozstrzyga się o uprawnieniach lub obowiązkach w ramach uznania administracyjnego, gdy ich treść, rozmiar, sposób wykonania lub jeszcze inne elementy są elastycznie kształtowane przez organ administracji publicznej lub gdy są one podzielane co do wielkości, wymiaru czasowego bądź terytorialnego. W tym ujęciu "charakter sprawy" determinujący możliwość prowadzenia w niej postępowania mediacyjnego wyznaczany jest przez elementy przedmiotowe sprawy administracyjnej. Wiąże się on przy tym z kompetencją do posługiwania się przez organ administracji publicznej uznaniem administracyjnym lub wynikającą z materialnoprawnej podstawy danej sprawy elastycznością w kształtowaniu jej rozstrzygnięcia ${ }^{24}$.

Przedstawiony przegląd stanowisk doktryny pozwala przyjąć, że dopuszczalność mediacji ze względu na charakter sprawy (art. 96a § 1 k.p.a.) należy wiązać z treścią normy prawa materialnego, która konkretyzowana jest $\mathrm{w}$ danym postępowaniu, a dokładniej - z zakresem wynikającego z niej luzu decyzyjnego, którym dysponuje organ administracji publicznej. Jeśli więc norma prawa materialnego przyznaje organowi kompetencję do stosowania uznania administracyjnego, posługuje się pojęciami niedookreślonymi lub innego rodzaju luzami decyzyjnymi, to $\mathrm{w}$ takim przypadku mediacja jest dopuszczalna. Nie bez znaczenia są także normy prawa procesowego. Wydaje się bowiem,

${ }^{22}$ Zob. A. Jakubowski, Art. 96a, w: Kodeks postępowania administracyjnego. Komentarz, pod red. M. Wierzbowskiego, A. Wiktorowskiej, Legalis/el. 2017.

${ }^{23}$ Zob. S. Gajewski, Kodeks postępowania..., s. 7-8.

${ }^{24}$ Zob. A. Kocot-Łaszczyca, G. Łaszczyca, op. cit., s. 70-71. 
że za dopuszczalnością mediacji w danej sprawie przemawia także posłużenie się przez ustawodawcę swobodną oceną dowodów. W takich przypadkach mediacja obejmować powinna również ocenę materiału dowodowego i interpretację ustalonych na jego podstawie faktów istotnych dla rozstrzygnięcia sprawy.

\section{Dopuszczalność mediacji w postępowaniu w sprawach z zakresu ubezpieczeń społecznych}

Zgodnie z art. 180 § 2 k.p.a. przez sprawy z zakresu ubezpieczeń społecznych rozumie się sprawy wynikające z przepisów o ubezpieczeniach społecznych, o zaopatrzeniach emerytalnych i rentowych, o funduszu alimentacyjnym, a także sprawy wynikające z przepisów o innych świadczeniach wypłacanych z funduszów przeznaczonych na ubezpieczenia społeczne. Z przytoczonej definicji wynika, że pojęcie to obejmuje sprawy, które odpowiadają dwóm cechom: po pierwsze, mają charakter spraw administracyjnych, o których mowa w art. 1 pkt $1-2$ k.p.a., a zatem rozstrzygane są przez organ administracji publicznej w drodze decyzji; po drugie, ich podstawa prawna wynika z przepisów o ubezpieczeniach społecznych w szerokim znaczeniu, czyli dotyczących uprawnień lub obowiązków związanych ze świadczeniami z ubezpieczeń społecznych lub zaopatrzenia społecznego, a także z przepisów o funduszu alimentacyjnym ${ }^{25}$. Innymi słowy, sprawy z zakresu ubezpieczeń społecznych to sprawy administracyjne, które mają podstawę prawną w przepisach materialnego prawa ubezpieczeń społecznych w szerokim znaczeniu lub w przepisach o funduszu alimentacyjnym. Tak szerokie ujęcie kategorii „spraw z zakresu ubezpieczeń społecznych" powoduje, że niezbędne jest zawężenie dalszych rozważań. Będą one ograniczone do regulacji prawnych obowiązujących w systemie powszechnym, którego granice wyznaczone sa przez zakres przedmiotowy ustawy systemowej. Jest to o tyle uzasadnione, że w dużej mierze analogiczne do omawianych w dalszej części opracowania regulacje prawne zawierają przepisy dotyczące ubezpieczenia społecznego rolników (świadczenie w drodze wyjątku - art. 55 ust. 1-2 u.s.r., umorzenia należności z tytułu składek art. 41a ust. 1-2 u.s.r.), zaopatrzenia emerytalnego funkcjonariuszy służb mundurowych (świadczenie w drodze wyjątku - art. 8 ust. 1

${ }^{25}$ Por. B. Adamiak, op. cit., s. 931; A. Wróbel, w: M. Jaśkowska, A. Wróbel, Kodeks postępowania administracyjnego. Komentarz LEX, Warszawa 2016, s. 980-982. 
u.z.e.f.) czy zaopatrzenia emerytalnego żołnierzy zawodowych i ich rodzin (świadczenie w drodze wyjątku - art. 8 ust. 1 u.z.z.r.).

W tym kontekście należy zwrócić uwagę, że w literaturze przedmiotu podkreśla się, iż jedną z cech materialnego prawa ubezpieczeń społecznych jest bezwzględnie wiążący charakter norm, które się na nie składają (ius cogens) ${ }^{26}$. W tej dziedzinie prawa ustawodawca dąży bowiem do maksymalnego ograniczenia luzów decyzyjnych po stronie organów administracji publicznej rozstrzygających o uprawnieniach do świadczeń z ubezpieczeń społecznych i ich wysokości. Wynika to w dużej mierze z okoliczności, że rozstrzygnięcia w tych sprawach wiążą się z dokonywaniem znacznych wydatków ze środków publicznych. Dążenie to znajduje zresztą odzwierciedlenie nie tylko w regulacji prawnomaterialnej, ale także procesowej, która zmierza do wyeliminowania luzów decyzyjnych po stronie organu rentowego ${ }^{27}$. Typową cechą postępowań w tych sprawach jest bowiem zamknięty katalog środków dowodowych oraz daleko idące ograniczenia w ich swobodnej ocenie. Decyzje w postępowaniach w sprawach z zakresu ubezpieczeń społecznych mają więc co do zasady charakter związany. Z tych powodów poza okolicznością, że w postępowaniach tych nie występują z reguły strony o spornych interesach - w literaturze podnosi się, że nie jest dopuszczalne zawieranie w nich ugody administracyjnej (art. 114-122 k.p.a.) $)^{28}$, a zasada polubownego załatwiania spraw spornych (art. 13 k.p.a.) ma w nich co najmniej ograniczone zastosowanie ${ }^{29}$.

Konstatacja ta rzutuje w istotny sposób na dopuszczalność prowadzenia mediacji w sprawach z zakresu ubezpieczeń społecznych. Można bowiem przyjąć, że jest ona każdorazowo wyłączona tam, gdzie w treści norm prawa materialnego nie znajduje się upoważnienie do uznania administracyjnego lub nie występują w niej pojęcia niedookreślone, a jeśli nawet - to regulacja procesowa dotycząca ich ustalenia jest na tyle szczegółowa, że eliminuje w istocie dyskrecjonalność po stronie organu. Ten stan rzeczy występuje w odniesieniu do większości postępowań z zakresu ubezpieczeń społecznych. Nie oznacza to jednak, że we wszystkich tych sprawach prowadzenie mediacji będzie

${ }^{26}$ Zob. K. Antonów, op. cit., s. 24.

${ }^{27}$ Por. Rozporządzenie Ministra Pracy i Polityki Społecznej z dnia 11 X 2011 r. w sprawie postępowania o świadczenia emerytalno-rentowe (Dz.U. Nr 237, poz. 1412), dalej "r.p.s.e.r.".

${ }^{28}$ Zob. K. Antonów, op. cit., s. 24.

${ }^{29}$ Zob. S. Gajewski, Stosowanie Kodeksu..., s. 31. 
niedopuszczalne. Wypada bowiem wskazać postępowania, w których organ rentowy wydaje rozstrzygnięcia, korzystając z upoważnienia do uznania administracyjnego, a jednocześnie przesłanki ich podjęcia wyrażone są pojęciami niedookreślonymi. Są to: (1) postępowanie w sprawie przyznania przez Prezesa Rady Ministrów świadczenia specjalnego (art. 82 ustawy emerytalnej); (2) postępowanie w sprawie przyznania przez Prezesa Zakładu Ubezpieczeń Społecznych świadczenia w drodze wyjątku (art. 83 ustawy emerytalnej); (3) postępowanie w sprawie umorzenia przez Zakład Ubezpieczeń Społecznych należności z tytułu składek na ubezpieczenia społeczne (art. 28 ustawy systemowej).

Stwierdzenie, że w określonych postępowaniach istnieją po stronie organu luzy decyzyjne, które umożliwiają przeprowadzenie mediacji, nie jest jednak wystarczające dla oceny celowości wdrażania tej formy postępowania wyjaśniającego w warunkach typowej sprawy, która jest w nich załatwiana. Do tego bowiem niezbędne jest zbadanie rzeczywistego zakresu dyskrecjonalności, którą będzie dysponował organ, prowadząc to postępowanie i wydając decyzję. $Z$ tego powodu wypada przeanalizować przepisy prawa materialnego, które stanowią podstawy prawne do załatwienia sprawy w wymienionych postępowaniach, a także - w niezbędnym zakresie - dotyczące ich regulacje procesowe.

Zgodnie z art. 82 ust. 1 ustawy emerytalnej w szczególnie uzasadnionych przypadkach Prezes Rady Ministrów może przyznać emeryturę lub rentę na warunkach i w wysokości innej niż określone w tej ustawie. Przepis ten wprowadza więc po stronie Prezesa Rady Ministrów uznaniową kompetencję do przyznania świadczenia (emerytury, renty z tytułu niezdolności do pracy, renty rodzinnej) osobom, które nie nabyły w świetle obowiązujących przepisów do niego prawa, albo - do ustalenia osobom, które je uzyskały na zasadach ogólnych, wysokości lub warunków otrzymywania i pobierania tego świadczenia bardziej korzystnych niż wynikające ze wspomnianych przepisów. Artykuł 82 ust. 1 ustawy emerytalnej deklaruje więc po stronie Prezesa Rady Ministrów bardzo szeroki zakres dyskrecjonalności. Z jednej strony bowiem organ ten może swobodnie rozstrzygać o prawie do świadczenia, jego rodzaju oraz wysokości (uznanie administracyjne), z drugiej natomiast samo przyznanie świadczenia uzależnione jest jedynie od spełnienia nieostrej przesłanki uzasadnionych przyczyn (pojęcie niedookreślone) ${ }^{30}$.

${ }^{30}$ Por. M. Bartnicki, Świadczenia przyznawane w szczególnym trybie, w: Emerytury i renty z Funduszu Ubezpieczeń Społecznych. Emerytury pomostowe. Okresowe emerytury kapitałowe. Komentarz, pod red. K. Antonowa, Warszawa 2014, s. 466-467; Ł. Prasołek, Świadczenia 
Sprowadza się ona do wskazania celów, które chronione są przez polski system prawny lub aprobowane w świetle społecznego systemu ocen i wartości, a które - w ocenie Prezesa Rady Ministrów - uzasadniają przyznanie określonej osobie świadczenia specjalnego. Inne przepisy nie wprowadzają przy tym reguł proceduralnych dotyczących postępowania wyjaśniającego, które ograniczałyby zakres swobody tego organu przy ustalaniu stanów odpowiadających treści przytoczonego pojęcia. Pozwala to przyjąć, że w sprawach załatwianych w postępowaniach dotyczących świadczeń specjalnych przeprowadzenie mediacji między organem a stroną rokuje osiągnięcie wszystkich jej celów wymienionych w art. 96a $\S 3$ k.p.a., tj. wyjaśnienia i rozważenia okoliczności faktycznych i prawnych sprawy oraz dokonania ustaleń dotyczących jej załatwienia w drodze decyzji. Organ ma tutaj bowiem daleko idąca swobodę zarówno w odniesieniu do sposobu ustalania faktów w tym postępowaniu, jak i podejmowanego $\mathrm{w}$ nim rozstrzygnięcia.

Stosownie do art. 83 ust. 1 ustawy emerytalnej ubezpieczonym oraz pozostałym po nich członkom rodziny, którzy wskutek szczególnych okoliczności nie spełniają warunków wymaganych w ustawie do uzyskania prawa do emerytury lub renty, nie mogą - ze względu na całkowitą niezdolność do pracy lub wiek - podjąć pracy lub działalności objętej ubezpieczeniem społecznym i nie mają niezbędnych środków utrzymania, Prezes Zakładu Ubezpieczeń Społecznych może przyznać w drodze wyjątku świadczenia w wysokości nieprzekraczającej odpowiednich świadczeń przewidzianych w ustawie. Paragraf 39 r.p.s.e.r. określa środki dowodowe, które stosuje się w postępowaniu o przyznanie takich świadczeń. Są to: zaświadczenia, inne dokumenty oraz oświadczenia strony. Przepis ten wskazuje przy tym okoliczności faktyczne i prawne, które ustala się za pomocą poszczególnych kategorii wspomnianych dowodów. W ten sposób, ograniczając luzy decyzyjne organu w postępowaniu dowodowym, jednocześnie wprowadza on w istocie katalog przesłanek warunkujących możliwość przyznania świadczenia w drodze wyjątku, a przynajmniej podlegających obligatoryjnemu rozważeniu w toku postępowania w tej sprawie. Mowa tu o: źródłach osiąganego przychodu, jego wysokości ( $\$ 39$ ust. 1 pkt 1 r.p.s.e.r.), aktualnym zatrudnieniu, prowadzeniu innej działalności zarobkowej (§ 39 ust. 1 pkt 2 r.p.s.e.r.), wysokości świadczeń otrzymywanych na podstawie

przyznawane w szczególnym trybie, w: Emerytury i renty z Funduszu Ubezpieczeń Społecznych. Emerytury pomostowe. Komentarz, pod red. B. Gudowskiej, K. Ślebzaka, Warszawa 2013, s. 563-566. 
odrębnych przepisów ( $\$ 39$ ust. 1 pkt 3 r.p.s.e.r.), posiadaniu gospodarstwa rolnego oraz jego wielkości i rodzaju (§ 39 ust. 1 pkt 4 r.p.s.e.r.), a także - sytuacji rodzinnej, majątkowej i materialnej zainteresowanego oraz najbliższych członków jego rodziny, z którymi prowadzi gospodarstwo domowe ( $\$ 39$ ust. 1 pkt 5 r.p.s.e.r.). Pojęcie niezdolności do pracy zostało natomiast zdefiniowane w art. 12-13 ustawy emerytalnej, a sposób jego ustalania, z udziałem lekarza orzecznika Zakładu Ubezpieczeń Społecznych (jego komisji lekarskiej) - w art. 14 tej ustawy. Dyskrecjonalność Prezesa Zakładu Ubezpieczeń Społecznych w omawianym postępowaniu jest więc dość wąska. Sprowadza się ona bowiem z jednej strony do oceny przyczyn powstania sytuacji uzasadniającej przyznanie świadczenia w drodze wyjątku („,szczególne okoliczności" - art. 83 ust. 1 ustawy emerytalnej), z drugiej natomiast do uznania administracyjnego przy ustalaniu rozstrzygnięcia w tym zakresie (pozytywne, negatywne). $Z$ tego powodu należy przyjąć, że prowadzenie mediacji między organem a stroną $\mathrm{w}$ postępowaniach dotyczących świadczeń $\mathrm{w}$ drodze wyjątku z reguły nie będzie celowe, choć - w sensie prawnym - jest w pełni dopuszczalne.

Zgodnie $\mathrm{z}$ art. 28 ust. 1 ustawy systemowej należności z tytułu składek mogą być umarzane w całości lub w części przez Zakład Ubezpieczeń Społecznych, przy czym może to nastąpić wyłącznie w przypadku ich całkowitej nieściągalności, chyba że zachodzi uzasadniony przypadek, a zaległe należności dotyczą ubezpieczonych, którzy są jednocześnie płatnikami składek (art. 28 ust. 3a ustawy systemowej). Ustawodawca wyposażył więc organ rentowy w kompetencję do posłużenia się uznaniem administracyjnym. Odnosi się ona przy tym zarówno do charakteru rozstrzygnięcia (pozytywne, negatywne), jak i do jego zakresu. Zakład Ubezpieczeń Społecznych rozstrzyga bowiem nie tylko, czy umorzyć należności z tytułu składek, ale także - czy uczynić to w całości czy w części. Przesłanką warunkującą dopuszczalność umorzenia należności jest całkowita nieściągalność. Pojęcie to zostało zdefiniowane w art. 28 ust. 3 ustawy systemowej. Ustawodawca odwołuje się w nim do różnych stanów faktycznych i prawnych, które pozwalają przyjąć, że wyegzekwowanie zadłużenia $z$ tytułu składek na ubezpieczenia społeczne od płatnika nie jest możliwe. Zostały one sformułowane za pomoca zwrotów o różnym stopniu ostrości, w tym tak niedookreślonych, jak wskazana w art. 28 ust. 2 pkt 6 ustawy systemowej przesłanka wskazująca, że całkowita nieściągalność zachodzi, gdy jest oczywiste, 
że w postępowaniu egzekucyjnym nie uzyska się kwot przekraczających wydatki egzekucyjne. $Z$ kolei szczegółowe warunki umorzenia składek pomimo braku ich całkowitej nieściągalności wymieniono w rozporządzeniu wydanym na podstawie art. 28 ust. $3 b$ tej ustawy ${ }^{31}$. Paragraf 3 ust. 1 r.s.z.u.n. przewiduje, że Zakład może umorzyć należności z tytułu składek, jeśli zobowiązany wykaże, że ze względu na stan majątkowy i sytuację rodzinną nie jest w stanie opłacić tych należności, ponieważ pociągnęłoby to zbyt ciężkie skutki dla zobowiązanego i jego rodziny, w szczególności w przypadku: (1) gdy opłacenie należności z tytułu składek pozbawiłoby zobowiązanego i jego rodzinę możliwości zaspokojenia niezbędnych potrzeb życiowych; (2) poniesienia strat materialnych w wyniku klęski żywiołowej lub innego nadzwyczajnego zdarzenia, powodujących, że opłacenie należności z tytułu składek mogłoby pozbawić zobowiązanego możliwości dalszego prowadzenia działalności; (3) przewlekłej choroby zobowiązanego lub konieczności sprawowania opieki nad przewlekle chorym członkiem rodziny, pozbawiającej zobowiązanego możliwości uzyskiwania dochodu umożliwiającego opłacenie należności.

Taki kształt przesłanek umorzenia należności z tytułu składek pozwala przyjąć, że zostały one w znacznej mierze sformułowane za pomocą pojęć niedookreślonych, w tym zwrotów szacunkowych, które nie poddają się jednoznacznej wykładni i mogą podlegać uszczegółowieniu jedynie na gruncie konkretnego przypadku (np. „jest oczywiste, że w postępowaniu egzekucyjnym nie uzyska się kwot przekraczających wydatki egzekucyjne" - art. 28 ust. 3 pkt 6 ustawy systemowej; "zbyt ciężkie skutki dla zobowiązanego i jego rodziny" - $\$ 3$ ust. 1 r.s.z.u.n.; "niezbędne potrzeby życiowe" - $\$ 3$ ust. 1 pkt 1 r.s.z.u.n.; "możliwości dalszego prowadzenia działalności" - $\$ 3$ ust. 1 pkt 2 r.s.z.u.n.). Przesłanki te - przynajmniej w części - mogą przy tym występować zarówno łącznie, jak i odrębnie, a rzeczą organu rentowego jest ustalenie na gruncie konkretnej sprawy rozmiarów odpowiadających im stanów faktycznych, które są wystarczające dla umorzenia należności z tytułu składek. Jednocześnie wypada zwrócić uwagę, że stany faktyczne badane w postępowaniu w sprawie umorzenia należności z tytułu składek na ubezpieczenia społeczne są niezwykle złożone, a ustawodawca nie wprowadził szczególnych regulacji procesowych dotyczących ich

${ }^{31}$ Rozporządzenie Ministra Gospodarki, Pracy i Polityki Społecznej z dnia 31 VII 2003 r. w sprawie szczegółowych zasad umarzania należności z tytułu składek na ubezpieczenia społeczne (Dz.U. Nr 141, poz. 1365), dalej „r.s.z.u.n.”. 
ustalania. Oznacza to, że organ rentowy powinien się w tym zakresie kierować zasadą swobodnej oceny dowodów (art. 80 k.p.a.).

W tym kontekście można wskazać, że w sprawach umorzenia należności z tytułu składek na ubezpieczenia społeczne można zidentyfikować wszystkie niezbędne dla stwierdzenia dopuszczalności mediacji luzy decyzyjne: uznanie administracyjne, pojęcia niedookreślone i swobodną ocenę dowodów. Luzy te mają przy tym bardzo szeroki charakter. Przesądza to nie tylko o prawnej dopuszczalności prowadzenia mediacji $\mathrm{w}$ tych sprawach, ale rokuje istotną przydatność w nich tej formy postępowania wyjaśniającego.

\section{Podsumowanie}

Mediacja jako forma postępowania wyjaśniającego jest dopuszczalna wówczas, gdy konkretyzowana w postępowaniu norma prawa materialnego upoważnia do posłużenia się uznaniem administracyjnym, zawiera pojęcia niedookreślone lub przewiduje po stronie organu innego rodzaju luzy decyzyjne. Mediacja może znaleźć zastosowanie w szczególności w tych przypadkach, gdy regulacja postępowania dowodowego oparta została na swobodnej ocenie dowodów. Wówczas ta forma postępowania wyjaśniającego może posłużyć w szczególności do rozstrzygnięcia sporu między organem a stroną co do oceny materiału dowodowego lub interpretacji faktów istotnych dla rozstrzygnięcia sprawy.

Na tym tle można przyjąć, że w postępowaniu w sprawach z zakresu ubezpieczeń społecznych mediacja będzie mogła być prowadzona jedynie w postępowaniu w sprawie przyznania przez Prezesa Rady Ministrów świadczenia specjalnego; postępowaniu w sprawie umorzenia przez Zakład Ubezpieczeń Społecznych należności z tytułu składek na ubezpieczenia społeczne oraz postępowaniu w sprawie przyznania przez Prezesa Zakładu Ubezpieczeń Społecznych świadczenia w drodze wyjątku, a także - w analogicznych postępowaniach przewidzianych na gruncie przepisów o ubezpieczeniu społecznym rolników, zaopatrzeniu emerytalnym żołnierzy zawodowych i ich rodzin oraz zaopatrzeniu emerytalnym funkcjonariuszy służb mundurowych i ich rodzin. Można się przy tym spodziewać, że wdrożenie mediacji będzie celowe jedynie w przypadku postępowań dotyczących umorzenia należności z tytułu składek na ubezpieczenia społeczne oraz przyznania świadczeń specjalnych. Oznacza to, że ta forma postępowania wyjaśniającego nie 
znajdzie częstego zastosowania w praktyce prowadzenia postępowań w sprawach z zakresu ubezpieczenia społecznego. Za konstatacją tą przemawia także okoliczność, że posługiwanie się mediacją wymaga istotnych zmian w przyjętej kulturze administrowania ${ }^{32}$, a zatem - również mentalności urzędników oraz obywateli, którzy występują w postępowaniach w charakterze stron. Biorąc zaś pod uwagę uwarunkowania działalności organów rentowych, można się obawiać, że także ze wskazanych, pozaprawnych powodów, mediacja nie będzie częstą formą prowadzenia postępowania wyjaśniającego nawet w sprawach, w których w sensie prawnym jest dopuszczalna. Warto bowiem zwrócić uwagę, że organy rentowe, w tym zwłaszcza Zakład Ubezpieczeń Społecznych, z jednej strony zorganizowane są w sposób scentralizowany, odpowiadający modelowi klasycznej biurokracji Weberowskiej ${ }^{33}$, a z drugiej - prowadzone przed nimi postępowania cechuje masowość i względna powtarzalność stanów faktycznych i prawnych. Okoliczności te sprzyjają zaś posługiwaniu się utrwalonymi praktykami administrowania i niechęci do nowych, alternatywnych i niezgodnych z nimi form prowadzenia postępowania.

${ }^{32}$ Zob. A. Kocot-Łaszczyca, G. Łaszczyca, op. cit., s. 147. Zob. także uzasadnienie projektu ustawy o zmianie ustawy - Kodeks postępowania administracyjnego oraz niektórych innych ustaw (druk sejmowy nr 1183/VIII kadencja, s. 36).

${ }^{33}$ Zob. na temat biurokracji Weberowskiej jako modelu zarządzania w administracji publicznej: J. Łukasiewicz, Zarys nauki administracji, Warszawa 2007, s. 37-39; S. Mazur, Historia administracji publicznej, w: Administracja publiczna, pod red. J. Hausnera, Warszawa 2008, s. 54-55; E. Sokalska, Biurokracja jako metoda funkcjonowania nowoczesnej administracji w ujęciu Maksa Webera, "Studia Prawnoustrojowe” 2003, nr 2, s. 119-124. 